\title{
Organogênese in vitro de batata (Solanum tuberosum L.) cultivar Atlantic visando transformação genética
}

\section{In vitro organogenesis of potato (Solanum tuberosum L.) cultivar Atlantic for the genetic transformation}

\author{
Rodrigo Kelson Silva Rezende ${ }^{1 *}$; Moacir Pasqual ${ }^{2}$; Luciano Vilela Paiva \\ Renato Paiva; ${ }^{4}$ Tathiana Elisa Masetto ${ }^{5}$
}

\begin{abstract}
Resumo
A obtenção de cultivares comerciais de batata com resistência a fitopatógenos é uma alternativa muito promissora que a engenharia genética pode proporcionar, através da introdução de genes exógenos visando transformação genética. Para tal, torna-se imprescindível estabelecer um sistema eficiente de transformação, e neste sentido a determinação de um protocolo de organogênese in vitro é o passo fundamental para este processo. Objetivou-se determinar um protocolo eficiente para a transformação genética de batata $\mathrm{cv}$. Atlantic. A eficiência da organogênese in vitro é influenciada pelo tipo de explante e pelo tipo e concentrações de reguladores de crescimento utilizados. Segmentos internodais de batata cv. Atlantic apresentam melhor capacidade organogenética que explantes foliares. Recomenda-se utilizar o meio woody plant medium (WPM) suplementado com 1,0 $\mathrm{mg} \mathrm{L}^{-1}$ de ácido naftaleno-acético (ANA) + $5,0 \mathrm{mg} \mathrm{L}^{-1}$ de zeatina ribosídeo (ZEA), para se obter brotações em segmentos internodais, sendo que a carbenicilina $(\mathrm{Cb})$ adicionada a este meio potencializa esta formação. Para o processo de alongamento de brotos, este mesmo antibiótico quando adicionado ao meio WPM em concentrações crescentes (100; $250 ; 500 \mathrm{mg} \mathrm{L}^{-1}$ ) promove uma diminuição na altura de plantas, número de nós e comprimento radicular. Após o co-cultivo de segmentos internodais com Agrobacterium tumefaciens estas concentrações de Cb não são eficientes na eliminação da bactéria, o que compromete a organogênese. No entanto, é possível estabelecer um protocolo de organogênese in vitro de batata cv. Atlantic a partir de segmentos internodais não co-cultivados. Estes resultados serão úteis para futuros experimentos de transformação genética com esta e outras cultivares comerciais de batata.
\end{abstract}

Palavras-chave: Micropropagação, cultura de tecidos, Agrobacterium tumefaciens

\begin{abstract}
The obtaining of commercial cultivars of potato with resistance to the phytopatogen is a very promising alternative that the genetic engineering can provide, through the introduction of exogenous genes for the genetic transformation. In order to establish an efficient system of transformation, it is crucial first to optimize in vitro organogenesis protocol. This work aimed to establish an efficient protocol for the genetic transformation of potato cv. Atlantic. The efficiency of the in vitro organogenesis is influenced by the explant type and by the kind and concentrations of growth regulators used. Shoot segments of
\end{abstract}

\footnotetext{
${ }^{1}$ Prof. da Faculdade de Ciências Agrárias, Universidade Federal da Grande Dourados, UFGD, Dourados, MS. E-mail: rkelson@ ufgd.edu.br

${ }^{2}$ Prof. do Dept ${ }^{\circ}$ de Agricultura, Universidade Federal de Lavras, UFLA, Lavras, MG. E-mail: mpasqual@dag.ufla.br

${ }^{3}$ Prof. do Dept ${ }^{\circ}$ de Química, UFLA, Lavras, MG. E-mail: luciano@dqi.ufla.br

${ }^{4}$ Prof. do Dept ${ }^{0}$ de Biologia, UFLA, Lavras, MG. E-mail: renpaiva@dbi.ufla.br

${ }^{5}$ Prof $^{\mathrm{a}}$ do Dept ${ }^{\mathrm{o}}$ de Ciências Agrárias, Universidade Tecnológica Federal do Paraná, UTFPR, Pato Branco, PR. E-mail: tmasetto@ utfpr.edu.br

* Autor para correspondência
} 
potato cv. Atlantic present better organogenesis capacity than leaf explants. It is recommended to use the woody plant medium (WPM) supplied with $1,0 \mathrm{mg} \mathrm{L}^{-1}$ of naphthalene acetic acid (NAA) $+5,0 \mathrm{mg}$ $\mathrm{L}^{-1}$ of zeatin riboside (ZEA), to obtain shoots from shoot segments, and the carbenicilin $(\mathrm{Cb})$ added to this medium increased this formation. For the process to enlarge shoots, this same antibiotic when added to the WPM medium in growing concentrations $\left(100 ; 250 ; 500 \mathrm{mg} \mathrm{L}^{-1}\right)$ promoted a decrease in the height of plants, number of shoots and length of roots. After the co-cultivation of shoots segments with Agrobacterium tumefaciens these concentrations of $\mathrm{Cb}$ are not efficient in the elimination of the bacteria, which commits the organogenesis. However, it is possible to establish a protocol of in vitro organogenesis of potato $\mathrm{cv}$. Atlantic starting from shoots segments not co-cultivated. These results will be useful for futures experiments of genetic transformation with this and another commercials cultivars of potato.

Key words: Micropropagation, tissue culture, Agrobacterium tumefaciens

\section{Introdução}

A batata (Solanum tuberosum L.) é considerada a quarta fonte de alimento da humanidade, após arroz, trigo e milho. É cultivada em todo o mundo e, em alguns países, o seu consumo está em torno de 75$95 \mathrm{~kg}$ per capita/ano. A produção anual brasileira é superior a três milhões de toneladas e concentrase nas regiões tropical, $67 \%$, e subtropical, 33\% (AGRIANUAL, 2010).

As cultivares comerciais apresentam susceptibilidade a patógenos (por exemplo, Phytophtora infestans, Alternaria solani, Xanthomonas sp. e Erwinia carotovora subsp. carotovora) ocasionando queda da produtividade. Dessa forma, a introdução de genes exógenos em cultivares comerciais de batata, através da engenharia genética, apresenta um grande potencial tanto para estudos básicos quanto para o melhoramento desta espécie (REZENDE, 2008).

Os programas de melhoramento convencional de batata, para a obtenção de novas cultivares resistentes, confrontam-se com dificuldades que começam com a complexidade genética das cultivares comerciais, as quais são tetraplóides e altamente heterozigotas. Os produtores e industriais geralmente dão preferência às cultivares tradicionais já estabelecidas, mesmo que as novas possam apresentar vantagens comparativas como a presença de genes de resistência a doenças causadas por microorganismos (CAMPOS, 1995).
A batata apresenta características favoráveis importantes para a transformação genética, tais como susceptibilidade à infecção por Agrobacterium tumefaciens e a relativa facilidade com que plantas transgênicas têm sido regeneradas a partir de diferentes explantes, através da cultura de tecidos. Além disso, sua propagação vegetativa permite que a expressão clonal de um indivíduo transformante de batata ocorra sem variação epistática da expressão do transgene, a qual pode ocorrer durante a propagação sexual (VAYDA; BELKNAP, 1992).

Atualmente, a utilização de peptídeos antimicrobianos têm-se mostrado com um grande potencial para aplicações em humanos, outros animais e em plantas (SILVA; DAFFRE; BULET, 2000; BARBOSA et al., 2007; SARIKA; IQUEBAL; RAI, 2012). Trata-se de moléculas pequenas de até $5 \mathrm{kDa}$ que apresentam um amplo espectro de atividade contra microorganismos. O mecanismo de ação mais bem conhecido é através de sua inserção na membrana celular que causa a destruição ou a permeabilização da mesma, levando o microrganismo à morte. Neste contexto, pode-se destacar o gene que codifica para o peptídeo antimicrobiano gomesina, o qual pode ser encontrado na hemolinfa da aranha-caranguejeira (Acanthoscurria gomesiana). A gomesina apresenta amplo espectro de atividade antimicrobiana (fungos e bactérias), causadora de várias doenças em culturas de interesse econômico. Em relação à batata, podese citar, por exemplo, a podridão mole causada por Erwinia carotovora subsp. carotovora, responsável 
por grandes perdas de produtividade (ANDREU; RIVAS, 1998).

Para se obter uma planta transgênica é necessário regenerar plantas a partir de células transformadas, devendo-se estabelecer um protocolo de regeneração via cultura de tecidos para o particular genótipo de interesse (VISSER, 1991).

Contudo, os resultados são muitas vezes divergentes e nem sempre é possível a reprodução dos mesmos pelo fato de que, provavelmente, a regulação fisiológica do processo de regeneração é cultivar dependente (PEREIRA; FORTES, 2003).

Variáveis como meio de cultura, o tipo e a concentração de fitormônios e antibióticos, o tipo e tamanho de explantes, as condições e o tempo de cultivo in vitro, são relevantes para um protocolo de transformação genética (REZENDE, 2008).

Desta forma, o objetivo deste trabalho foi estabelecer um protocolo eficiente de organogênese in vitro de batata cv. Atlantic, visando transformação genética.

\section{Material e Métodos}

O presente trabalho foi realizado no Laboratório Central de Biologia Molecular (LCBM-UFLA), em parceria com o Laboratório de Cultura de Tecidos de Plantas, do setor de Fisiologia Vegetal, no Departamento de Biologia, da Universidade Federal de Lavras (UFLA), em Lavras, MG.

Indução de regeneração - Plantas de batata cv. Atlantic, oriundas do cultivo in vitro de meristemas, foram cedidas pela empresa Multiplanta Tecnologia Vegetal(Andradas-MG).Utilizou-se como explantes segmentos internodais (sem gemas laterais) medindo 0,7 - 0,8 cm de comprimento, e também explantes foliares de $0,8-1,0 \mathrm{~cm}^{2}$ contendo a nervura central, oriundos de plantas pré-estabelecidas in vitro, com três a quatro semanas de idade.

Os explantes foram inoculados em meio WPM (LLOYD; MCCOWN, 1980) sólido (6 g L-1 de ágar), acrescido de $30 \mathrm{~g} \mathrm{~L}^{-1}$ de sacarose e suplementado com diferentes tipos e concentrações de reguladores de crescimento (ANA: ácido naftaleno-acético, AIA: ácido indol-3-acético e ZEA: zeatina ribosídeo), realizando-se a interação entre diferentes doses desses reguladores de crescimento (Tabela 1).

Tabela 1. Tratamentos obtidos por meio da interação entre diferentes concentrações de ácido naftaleno-acético (ANA), ácido indol-3-acético (AIA) e zeatina ribosídeo (ZEA).

\begin{tabular}{cccc}
\hline Tratamento & ANA $\left(\mathbf{m g ~ L}^{-\mathbf{1}}\right)$ & AIA $\left(\mathbf{m g ~ L}^{-1}\right)$ & ZEA $\left(\mathbf{m g ~ L}^{-\mathbf{1}}\right)$ \\
\hline T1 & 0 & 0 & 0 \\
T2 & 0,1 & 0 & 0,1 \\
T3 & 0,1 & 0 & 1,0 \\
T4 & 0,1 & 0 & 5,0 \\
T5 & 1,0 & 0 & 0,1 \\
T6 & 1,0 & 0 & 1,0 \\
T7 & 1,0 & 0 & 5,0 \\
T8 & 0 & 0,1 & 0,1 \\
T9 & 0 & 0,1 & 1,0 \\
T10 & 0 & 0,1 & 5,0 \\
T11 & 0 & 1,0 & 0,1 \\
T12 & 0 & 1,0 & 1,0 \\
T13 & 0 & 1,0 & 5,0 \\
\hline
\end{tabular}

Fonte: (REZENDE, 2008). 
Cada tratamento consistiu de três repetições (placas) com 10 explantes cada. As placas foram incubadas durante 30 dias em sala de crescimento com temperatura de $23{ }^{\circ} \mathrm{C} \pm 1{ }^{\circ} \mathrm{C}$, fotoperíodo de 16 horas e irradiância de fótons de $43 \mu \mathrm{mol} \mathrm{m} \mathrm{m}^{-2} \mathrm{~s}^{-1}$. As variáveis avaliadas após 30 dias foram: percentual (\%) de formação de calos, \% de formação de raízes e \% de formação de brotos.

Influência da carbenicilina sobre a taxa de regeneração de brotos e plântulas normais Objetivou-se testar a influência da suplementação do antibiótico carbenicilina $(\mathrm{Cb})$ ao melhor meio de indução de brotos (MIB), obtido no experimento anterior sobre a taxa de regeneração direta, e posteriormente verificar o comportamento destas brotações na regeneração de plântulas normais. Segmentos internodais (sem gemas laterais) foram cultivados em meio WPM sólido, acrescido de $30 \mathrm{~g} \mathrm{~L}^{-1}$ de sacarose e suplementado com 1,0 mg $\mathrm{L}^{-1}$ de ANA + 5,0 mg L ${ }^{-1}$ de ZEA, e Cb $(0 ; 100$; $\left.250 ; 500 \mathrm{mg} \mathrm{L}^{-1}\right)$. Foram inoculados 10 explantes por placa de Petri contendo $30 \mathrm{~mL}$ de meio de cultura, com cinco repetições por tratamento. Os explantes permaneceram incubados durante 30 dias em sala de crescimento sob as condições já descritas anteriormente. Posteriormente, estes foram transferidos para frascos de vidro (com capacidade de $250 \mathrm{~mL}$ ) contendo $40 \mathrm{~mL}$ do meio MIB suplementado com $\mathrm{Cb}(0 ; 100 ; 250 ; 500$ $\mathrm{mg} \mathrm{L^{-1 }}$, onde permaneceram por mais 30 dias. Após 60 dias em cultura, todos os explantes foram individualmente observados e, com auxílio de estereomicroscópio, efetuou-se a contagem do número de segmentos internodais que deram origem a brotações, sendo posteriormente calculada a percentagem. A partir destas botações, excisou-se segmentos nodais de $0,8-1,0 \mathrm{~cm}$ de comprimento apresentando uma única gema axilar. Estes foram inoculados em tubos de ensaio, contendo o meio WPM sólido, acrescido de $30 \mathrm{~g} \mathrm{~L}^{-1}$ de sacarose e suplementado com $\mathrm{Cb}(0 ; 100 ; 250 ; 500 \mathrm{mg}$ $\left.\mathrm{L}^{-1}\right)$. Utilizou-se o delineamento experimental inteiramente casualizado. Foi colocado um explante por tubo de ensaio, com 12 repetições por tratamento. Os tubos foram incubados em sala de crescimento sob temperatura de $23{ }^{\circ} \mathrm{C} \pm 1{ }^{\circ} \mathrm{C}$, fotoperíodo de 16 horas e irradiância de fótons de $43 \mu \mathrm{mol} \mathrm{m}^{-2} \mathrm{~s}^{-1}$. Após um período de 30 dias as plantas crescidas a partir de gemas axilares foram observadas quanto à altura, número de nós e comprimento de raízes, sendo os dados submetidos à análise de variância, com realização do teste de $\mathrm{F}$, utilizando-se o software $\operatorname{Sisvar}^{\circledR}$ (FERREIRA, 1998). Em caso de observação de diferenças significativas, efetuaramse análises de regressão.

Transformação genética de batata cv. Atlantic por Agrobacterium tumefaciens - Utilizou-se a cepa desarmada de Agrobacterium tumefaciens EHA 105 transformada com o vetor pCG1X que contém o gene da gomesina sob o controle do promotor 35S CaMv duplicado. Culturas de EHA 105 foram crescidas em meio LB (MILLER, 1972), pH ajustado para 7,5 e geleificado com 1,6 $\mathrm{g} \mathrm{L}^{-1}$ de ágar, contendo antibióticos apropriados: Rifampicina (Rf) e Canamicina (Kan), ambos em concentração de $100 \mathrm{mg} \mathrm{L}{ }^{-1}$, a $28{ }^{\circ} \mathrm{C}$, durante 48 horas.

Posteriormente, duas a três colônias da cultura anterior foram repicadas em erlenmeyers (capacidade $50 \mathrm{~mL}$ ), contendo $15 \mathrm{~mL}$ do mesmo meio líquido e suplementado com Rf e Kan (100 mg $\mathrm{L}^{-1}$ ), e cultivadas sob agitação de $80 \mathrm{rpm}$, no escuro, a $28^{\circ} \mathrm{C}$, durante 48 horas.

Segmentos internodais de batata cv. Atlantic foram excisados de plantas crescidas in vitro, sendo imersos numa diluição $10^{-1}$ da cultura da bactéria em meio WPM líquido. Foram co-cultivados 30 segmentos internodais por placa de Petri com células de $A$. tumefaciens EHA-105 (O.D.600 ${ }_{\mathrm{nm}}=$ $1,0)$ por $48 \mathrm{~h}$ em placas, vedadas com parafilme, a $28 \pm 1{ }^{\circ} \mathrm{C}$, no escuro, sob agitação de $80 \mathrm{rpm}$. Lavou-se os segmentos internodais três vezes em água estéril, durante cinco minutos, sendo que na última lavagem adicionou-se $500 \mathrm{mg} \mathrm{L}^{-1}$ de $\mathrm{Cb}$. Em seguida, os explantes foram secos em papel 
de filtro estéril, e inoculados em placas de Petri contendo meio de cultura para indução de brotos, suplementado com carbenicilina $(0 ; 100 ; 250$; 500 $\mathrm{mg} \mathrm{L}^{-1}$ ), para eliminar a Agrobacterium do meio de cultura. Explantes controles foram submetidos ao mesmo procedimento, entretanto sem adicionar bactéria.

As placas foram incubadas por 30 dias em sala de crescimento sob condições descritas anteriormente. Avaliou-se a eficiência da carbenicilina em eliminar a Agrobacterium do meio de cultura, bem como a capacidade de formação e desenvolvimento de brotos.

\section{Resultados e Discussão}

Indução de regeneração - Observou-se que a percentagem de calos e brotos formados variou de acordo com a fonte de explante, bem como o tratamento empregado (Figura 1, A e B).

A utilização de segmentos internodais, possibilitou a formação de calos e raízes em todos os tratamentos, exceto o controle (T1). As brotações foram formadas nos tratamentos T2 a T7 (Figura 1A). O tratamento T7 apresentou o melhor resultado, proporcionando $100 \%$ de calogênese e a maior formação de brotos (55\%). Não houve formação de brotos no tratamento controle (T1) e nos tratamentos em que se utilizou a combinação de AIA e ZEA. Neste caso, pode-se inferir que as auxinas AIA e ANA atuaram inibindo e favorecendo a formação de brotos, respectivamente.

Quando utilizou-se explantes foliares houve formação de calos e raízes em todos tratamentos (exceto T1), sem no entanto ocorrer a formação de brotações (Figura 1B).

A percentagem de formação de calos em explantes foliares foi inferior em todos os tratamentos, quando comparado com a utilização de segmentos internodais. $\mathrm{O}$ tratamento $\mathrm{T} 7$ mostrou-se mais eficiente para a formação de calos em segmentos internodais. Grande parte dos explantes foliares sofreram oxidação, possivelmente por ocasião do manuseio dos mesmos, originando calos de aspecto amarronzado e sem a capacidade de formar brotos.

Os resultados mostram que segmentos internodais são explantes ideais para a organogênese indireta (com formação de calos) em batata cv. Atlantic, devendo-se utilizar o meio WPM suplementado com 1,0 $\mathrm{mg} \mathrm{L}^{-1}$ de ANA + 5,0 $\mathrm{mg} \mathrm{L}^{-1}$ de ZEA (Figura 2).

Segundo Skoog e Miller (1957) níveis mais elevados de citocininas em relação aos de auxinas induzem a formação de brotos, conforme o tratamento T7 utilizando-se segmentos internodais. A utilização de AIA combinado com ZEA, promoveu a inibição da brotação para ambos tipos de explantes.

Torres et al. (2000), verificaram que na regeneração de plantas de batata cultivares Baronesa e Macaca, entrenós se mostraram mais eficentes que explantes foliares.

Campos (1995) trabalhando com batata cv. Baronesa, obteve $80 \%$ de calogênese e $46 \%$ de formação de brotos combinando-se diferentes concentrações de ZEA e ANA.

Torres et al. (2003), utilizou o meio MS suplementado com 2,0 $\mathrm{mg} \mathrm{L}^{-1}$ de ZEA, 3,0 $\mathrm{mg} \mathrm{L}^{-1}$ de AIA e $0,05 \mathrm{mg} \mathrm{L}^{-1}$ de $\mathrm{GA}_{3}$ (ácido giberélico) para as cultivares Baronesa e Macaca, obtendo resultados semelhantes para as duas cultivares.

Campos (2007) trabalhando com batata cv. Monalisa, obteve $100 \%$ de formação de calos e brotos a partir de segmentos internodais, utilizando meio MS suplementado com $0,05 \mathrm{mg} \mathrm{L}^{-1}$ de ANA, $0,1 \mathrm{mg} \mathrm{L}^{-1}$ de $\mathrm{GA}_{3}$ e $3,0 \mathrm{mg} \mathrm{L}^{-1}$ de ZEA.

Gustafson et al. (2006), trabalhando com batata cv. Shepody, utilizou combinações de ANA $(0 ; 0,1$; $\left.1,0 \mathrm{mg} \mathrm{L}^{-1}\right)$ e ZEA $\left(0 ; 0,1 ; 1,0 ; 5,0 \mathrm{mg} \mathrm{L}^{-1}\right)$ visando organogênese. 
Figura 1. Percentagem de formação de calos, brotos e raízes em segmentos internodais (A) e explantes foliares (B) de batata cv. Atlantic, após 30 dias de cultivo in vitro.
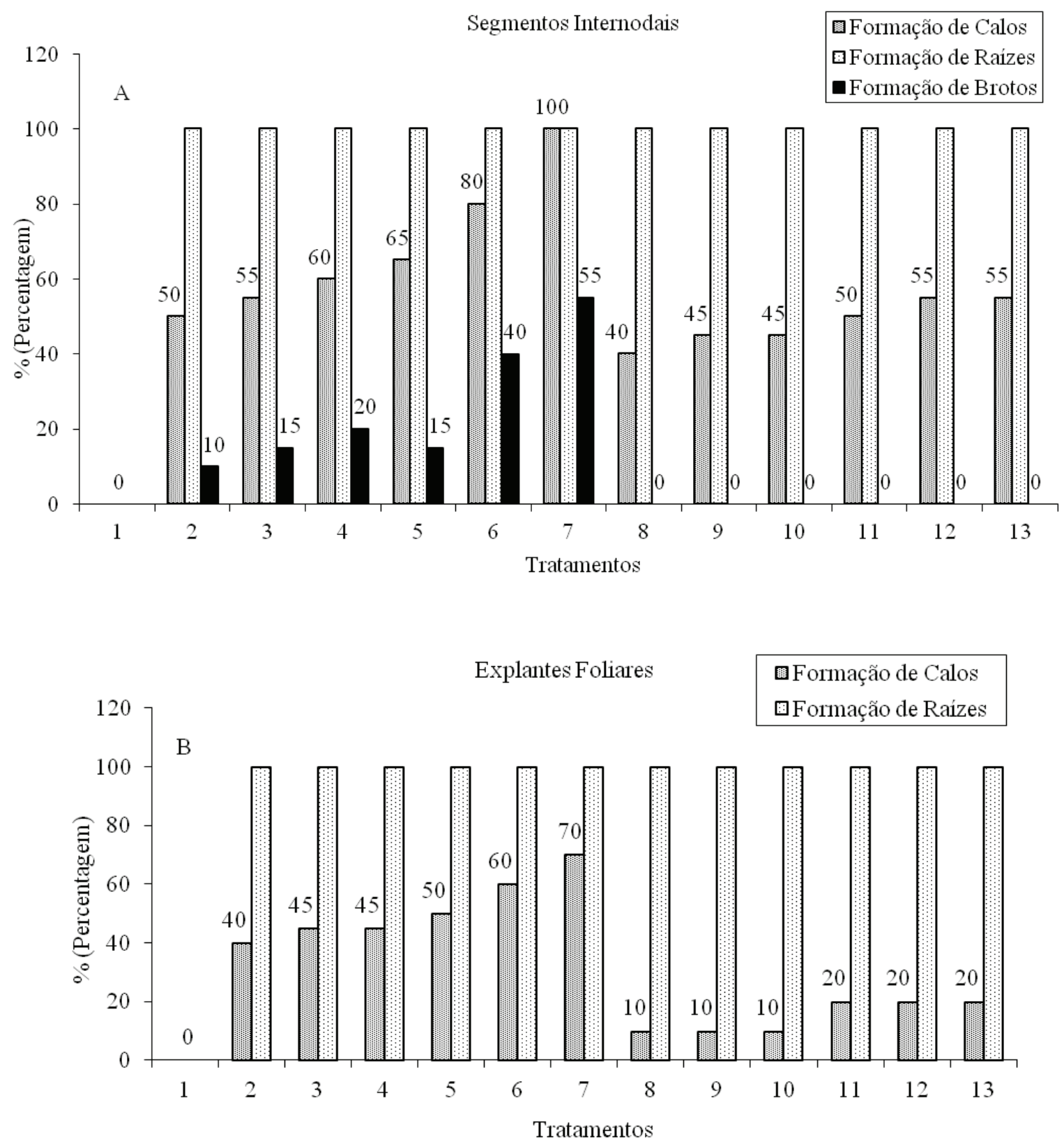

Fonte: (REZENDE, 2008). 
Figura 2. Organogênese indireta a partir de segmentos internodais de batata $\mathrm{cv}$. Atlantic, submetidos ao tratamento $\mathrm{T} 7$ (1,0 $\mathrm{mg} \mathrm{L}^{-1}$ de ANA + 5,0 $\mathrm{mg} \mathrm{L}^{-1}$ de ZEA). A: 30 dias de cultivo in vitro; B: 45 dias de cultivo in vitro; C: 60 dias de cultivo in vitro

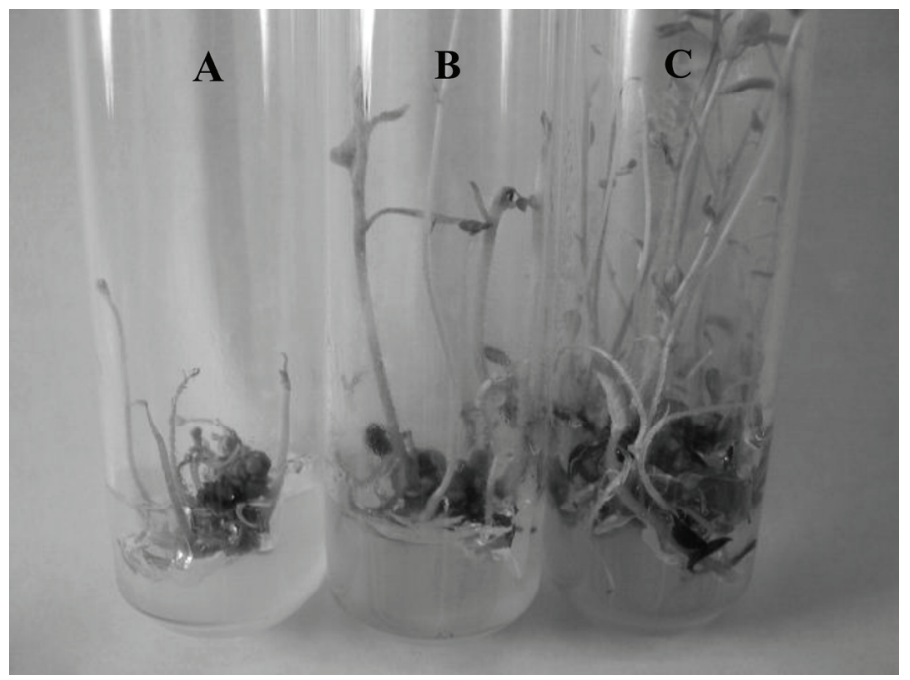

Fonte: (REZENDE, 2008).

Efeito de diferentes concentrações de carbenicilina sob a taxa de regeneração de brotos e desenvolvimento de plântulas normais - A carbenicilina é um antibiótico que tem sido usado com frequência para eliminar $A$. tumefaciens de células e tecidos vegetais após o co-cultivo em experimentos de transformação, mas poucos são os relatos na literatura sobre os eventuais efeitos do mesmo, sobre as respostas in vitro das espécies de plantas transformadas.
Aos 30 dias de cultivo os segmentos internodais tratados com antibióticos $\left(100 ; 250 ; 500 \mathrm{mg} \mathrm{L}^{-1}\right)$ apresentaram menor formação de brotos (38, 44 e $46 \%$ respectivamente) comparando-se ao tratamento controle - MIB (56\%). De 30 para 60 dias em cultura, houve um incremento no percentual de regeneração de segmentos internodais. Supõe-se que um incremento de 30 dias no tempo de cultivo, tenha favorecido a diferenciação de um maior número de células em brotos (Tabela 2).

Tabela 2. Número total de segmentos internodais e percentagem de formação de brotos em segmentos internodais de batata cv. Atlantic aos 30 e 60 dias, em função de diferentes doses de carbenicilina.

\begin{tabular}{cccc}
\hline \multirow{2}{*}{ Meios de Indução } & \multirow{2}{*}{$\begin{array}{c}\text { Notal de segmentos } \\
\text { internodais }\end{array}$} & \multicolumn{2}{c}{ Percentagem de formação de brotos (\%) } \\
\cline { 3 - 4 } & & Aos 30 dias & Aos 60 dias \\
\hline MIB & 50 & 56 & 58 \\
$\mathrm{MIB}+\mathrm{Cb}\left(100 \mathrm{mg} \mathrm{L}^{-1}\right)$ & 50 & 38 & 66 \\
$\mathrm{MIB}+\mathrm{Cb}\left(250 \mathrm{mg} \mathrm{L}^{-1}\right)$ & 50 & 44 & 72 \\
$\mathrm{MIB}+\mathrm{Cb}\left(500 \mathrm{mg} \mathrm{L}^{-1}\right)$ & 50 & 36 & 60 \\
\hline
\end{tabular}

Fonte: (REZENDE, 2008). 
O maior índice de segmentos internodais com brotos (72\%) ocorreu aos 60 dias em cultura, utilizando-se o meio contendo $250 \mathrm{mg} \mathrm{L}^{-1}$ de $\mathrm{Cb}$, indicando que a carbenicilina influencia na formação de novas brotações.

A análise de regressão polinomial para as variáveis altura de plantas, número de nós formados e comprimento de raízes em relação às concentrações de $\mathrm{Cb}$, foi expressa através de regressões lineares (Figura 3).

Os resultados ilustrados na Figura 3A indicam que a altura de plantas foi reduzida de acordo com o aumento da concentração de $\mathrm{Cb}$. Uma completa inibição do desenvolvimento das plântulas não foi observada em nenhuma das concentrações utilizadas. O número de nós formados nas plantas foi decrescente em relação à concentração de $\mathrm{Cb}$ (Figura 3B). Foram obtidos menores comprimentos de raízes utilizando-se maiores concentrações de $\mathrm{Cb}$ (Figura 3C). Aparentemente, a adição de carbenicilina ao meio de indução de brotos potencializou a regeneração dos explantes após 60 dias de cultivo.

Figura 3. Efeito de diferentes concentrações de carbenicilina $\left(0 ; 100 ; 250 ; 500 \mathrm{mg} \mathrm{L}^{-1}\right)$ sobre altura de plantas (A), número de nós formados (B) e comprimento de raízes (C) da cv. Atlantic, após 30 dias de cultivo.
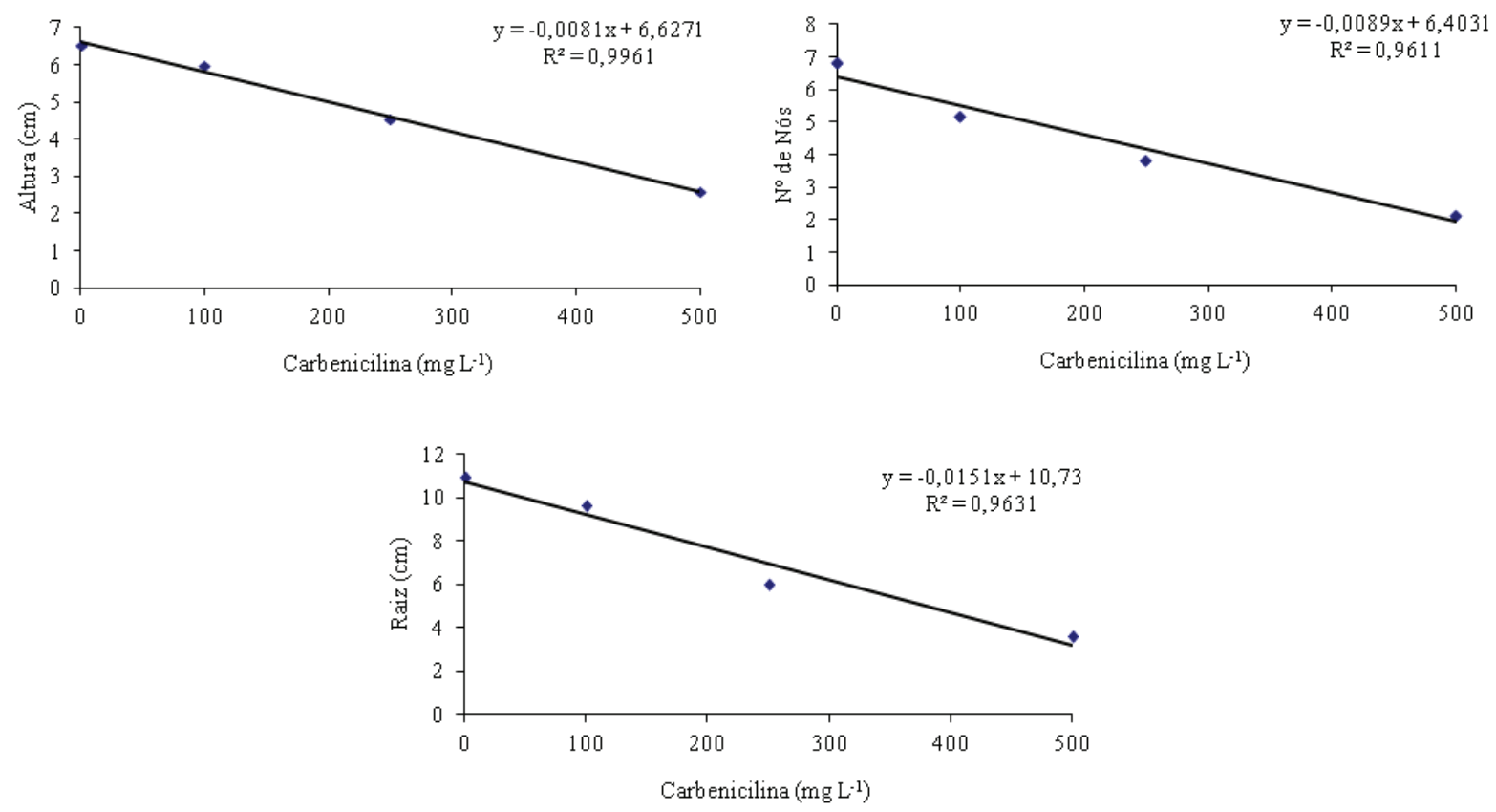

Fonte: (REZENDE, 2008).

Pollock, Barfield e Shields (1983), também observaram um incremento no crescimento de colônias de cloroplastos de Nicotiana plumbaginifolia proporcionado pela penicilina, ampicilina e carbenicilina, sendo observado a habilidade dessas substâncias agirem regulando o crescimento de plantas.
Campos (1995) encontrou respostas semelhantes adicionando-se $300 \mathrm{mg} \mathrm{L}^{-1}$ de $\mathrm{Cb}$ ao meio de indução de brotos, obtendo $77 \%$ de formação de brotos, em segmentos internodais de batata cv. Baronesa. Encontrou-se efeitos semelhantes para as variáveis altura de plantas, número de nós e comprimento de raízes, sendo que os valores destas variáveis 
diminuíram com doses crescentes de antibiótico suplementado ao meio para alongamento de brotos.

Transformação genética de batata cv. Atlantic por Agrobacterium tumefaciens - Não foi possível a formação de brotos em segmentos internodais de batata cv. Atlantic, co-cultivados com $A$. tumefaciens EHA 105. A carbenicilina não foi eficiente para a eliminação da bactéria. $\mathrm{O}$ contato da bactéria com os explantes, conferiu aos mesmos uma coloração esbranquiçada, contribuindo para a sua perda qualitativa.

Campos (1995), obteve sucesso no co-cultivo de explantes da cv. Baronesa com LBA 4404/pBi-PVY, verificando uma elevada interação entre a bactéria e este genótipo.

Spychalla e Bevan (1993) regeneraram brotos diretamente a partir de segmentos internodais transformados de batata cv. Desirée, sob meio de cultura contendo $3,0 \mathrm{mg} \mathrm{L}^{-1}$ de BAP $+0,01 \mathrm{mg} \mathrm{L}^{-1}$ de ANA + $500 \mathrm{mg} \mathrm{L}^{-1}$ de $\mathrm{Cb}+100 \mathrm{mg} \mathrm{L}^{-1}$ de Kan.

Gustafson et al. (2006), obteve com a utilização de $300 \mathrm{mg} \mathrm{L}^{-1}$ de cefotaxima $+100 \mathrm{mg} \mathrm{L}^{-1}$ de canamicina, em experimentos de transformação com a cultivar Shepody.

Para o controle de bactérias no cultivo in vitro, normalmente são utilizadas substâncias antibióticas que são incorporadas ao meio de cultura ou usadas diretamente sobre os explantes contaminados (SALEHI; KHOSH-KHUI, 1997).

É comum a utilização de elevadas concentrações de antibióticos, no entanto a fitotoxicidade dessas substâncias é fator limitante. Uma das alternativas é reduzir ao máximo o tempo do tratamento dos explantes com o antibiótico. Esta técnica muitas vezes causa efeitos apenas bacteriostáticos, constituindo uma ação paliativa frente ao principal objetivo que é a eliminação por completo do organismo contaminante (TENG; NICHOLSON, 1997).

Neste sentido, torna-se interessante testar outros antibióticos e diferentes concentrações que possam vir a eliminar a $A$. tumefaciens do meio de cultura, sem no entanto influenciar na organogênese in vitro. Esta determinação é um ponto crucial para a continuidade desse sistema de transformação genética.

\section{Conclusões}

Segmentos internodais de batata cv. Atlantic apresentam melhor capacidade organogenética em relação aos explantes foliares;

Recomenda-se utilizar o meio WPM suplementado com 1,0 mg L-1 de ANA + 5,0 mg L-1 de ZEA (meio MIB) para organogênese de batata cv. Atlantic;

A carbenicilina potencializa a formação de brotos em segmentos internodais de batata cv. Atlantic após 60 dias; promove uma diminuição na altura de plantas, número de nós e comprimento radicular e não é eficiente na eliminação de A. tumefaciens;

É possível estabelecer um protocolo de organogênese in vitro de batata cv. Atlantic a partir de segmentos internodais não co-cultivados.

\section{Referências}

AGRIANUAL. Anuário de agricultura brasileira. Batata. São Paulo: FNP Consultoria, 2010. p. 205-211.

ANDREU, D.; RIVAS, L. Animal antimicrobial peptides: an overview. Biopolymers, Malden, v. 6, n. 47, p. 415433, 1998.

BARBOSA, F. M.; DAFFRE, S.; MALDONADO, R. A.; MIRANDA, A.; NIMRICHTER, L.; RODRIGUES M. L. Gomesin, a peptide produced by the spider Acanthoscurria gomesiana, is a potent anticryptococcal agent that acts in synergism with fluconazole. FEMS Microbiology Letters, Malden, v. 274, n. 2, p. 279-286, 2007.

CAMPOS, M. A. Sistema de transformação de batata (Solanum tuberosum L.) cultivar Baronesa mediado por Agrobacterium tumefaciens. 1995. Dissertação (Mestrado em Agronomia, Fitomelhoramento) - Universidade Federal de Pelotas, Pelotas. 
CAMPOS, N. A. Embriogênese somática e regeneração eficiente de batata (Solanum tuberosum L.) cultivar Monalisa in vitro. 2007. Monografia (Graduação em Ciências Biológicas) - Universidade Federal de Lavras, Lavras.

FERREIRA, D. F. Sisvar: sistema de análise de variância para dados balanceados. Lavras: UFLA, 1998. 19 p.

GUSTAFSON, V.; MALLUBHOT, S.; MACDONNELL, J.; SANYAL-BAGCHI, M.; CHAKRAVARTY, B.; WANG-PRUSKI, G.; ROTHWELL, C.; AUDY, P.; DEKOEYER, D.; SIAHBAZI, M.; FLINN, B.; REGAN, S. Transformation and plant regeneration from leaf explants of Solanum tuberosum L. cv. Shepody. Plant Cell, Tissue and Organ Culture, Dordrecht, v. 85, n. 3, p. 361-366, 2006.

LLOYD, G.; McCOWN, B. Commercially-feasible micropropagation of mountain laurel, Kalmia latifolia, by use of shoot tip culture. Internacional Plant Popagation Society Proceedings, Washington, v. 30, p. 421-427, 1980.

MILLER, J. H. Experiments in molecular genetics. New York: Cold Spring Harbor, 1972.

PEREIRA, J. E. S.; FORTES, G. R. L. Protocolo para a produção de material propagativo de batata em meio líquido. Pesquisa Agropecuária Brasileira, Brasília, v. 38, n. 9, p. 1035-1043, 2003.

POLLOCK, K.; BARFIELD, D. G.; SHIELDS, R. The toxicity of antibiotics to plant cell cultures. Plant Cell Reports, New York, v. 2, p. 36-39, 1983.

REZENDE, R. K. S. Organogênese in vitro de batata (Solanum tuberosum L.) cultivar Atlantic visando transformação genética. 2008. Tese (Doutorado em Fisiologia Vegetal) - Universidade Federal de Lavras, Lavras.

SALEHI, H.; KHOSH-KHUI, M. A simple procedure for disinfection of "baby masquerade" miniature rose explants. Scientia Horticulturae, Amsterdam, v. 68, p. 145-148, 1997.

SARIKA; IQUEBAL, M. A.; RAI, A. Biotic stress resistance in agriculture through antimicrobial peptides. Peptides, Amsterdam, v. 36, n. 2, p. 322-330, 2012.
SILVA, P. I.; DAFFRE, S.; BULET, P. Isolation and full caracterization of gomesin, na 18-residue cysteinerich defense peptide from the spider Acanthoscurria gomesiana hemocytes with sequences similarities to horseshoe crab antimicrobial peptides of the tachyplesin family. Journal of Biological Chemistry, Bethesda, v. 275, n. 43, p. 33464-33470, 2000.

SKOOG, F.; MILLER, C. O. Chemical regulation of growth and organ formation in plant tissues cultures in vitro. Symposium for Society Experimental Biology, Cambridge, v. 11, p. 118-31, 1957.

SPYCHALLA, J. P.; BEVAN, M. W. Agrobacteriummediated transformation of potato stem and tuber tissue, regeneration and PCR screening for transformation. Plant Tissue Culture Manual, Kluwer Academic Publishers, The Netherlands, v. 11, p.1-18, 1993.

TENG, W. L.; NICHOLSON, L. Pulse treatments of penicillin-G and streptomycin minimize internal infections and have post-treatment effects on the morphogenesis of ginseng root culture. Plant Cell Reports, New York, v. 16, p. 531-535, 1997.

TORRES, A. C.; FERREIRA, A. T.; ROMANO, E.; CATTONY, M. K.; NASCIMENTO, A. S. Transformação genética de batata cultivar Achat via Agrobacterium tumefaciens. Horticultura Brasileira, Brasília, v. 18, n. 1, p. 41-45, 2000.

TORRES, A. C.; FERREIRA, A. T.; WIDHOLZER, C. F. N.; ROMANO, E.; PETERS, J. A. Expressão eficiente do gene reporter b-glucuronidase nos tecidos vasculares de batata (Solanum tuberosum L.) utilizando de um promotor específico (BRA3) de Agrobacterium rhizogenes. Horticultura Brasileira, Brasília, v. 21, n. 2, p.177-180, 2003.

VAYDA, M. E.; BELKNAP, W. R. The emergence of transgenic potatoes as commercial products and tools for basic science. Transgenic Research, v. 1, p. 149-163, 1992.

VISSER, R. G. F. Regeneration and transformation of potato by Agrobacterium tumefaciens. Plant Tissue Culture Manual, v. 5, p. 1-9, 1991. 